\title{
Study of Toxic Heavy Metals in Mahim Creek of Mumbai
}

\author{
P. U. Singare* ${ }^{*}$ S. E. L. Ferns \\ Department of Chemistry, Bhavan's College, Munshi Nagar, Andheri (West), \\ Mumbai - 400058, India \\ *E-mail address: pravinsingare@gmail.com
}

\begin{abstract}
The present study was performed for the period of one year from June 2012 to May 2013 in order to understand the level of toxic heavy metals in the water of Mahim Creek near Mumbai. It was observed that the annual average concentration of heavy metals like $\mathrm{Pb}, \mathrm{Cd}, \mathrm{Cr}, \mathrm{Fe}, \mathrm{Zn}, \mathrm{Cu}$ and $\mathrm{Ni}$ and $\mathrm{Hg}$ was found to be $0.68,0.28,0.15,0.04,2.93,0.64,1.29$ and $0.31 \mathrm{ppm}$ respectively. The average concentrations of $\mathrm{Hg}$ and $\mathrm{Pb}$ were found to be above the maximum permissible limit of 0.01 ppm and $0.1 \mathrm{ppm}$ respectively set for inland surface water by Central Pollution Control Board $(C P C B)$ of India. The results suggest that there is a need to have such regular scientific monitoring for longer time period in order to understand the variation in level of these toxic heavy metals discharged in to the creek water. It is feared that the existing problem if ignored may increase the pollution problem of the creek due to the toxic heavy metals resulting in threat to the biological life of an aquatic ecosystem. From the results of the present investigation it seems that the time has come to move towards ecosystem specific discharge standards to maintain the health and productivity of natural resources on which the majority of human population is dependent.
\end{abstract}

Keywords: heavy metals; toxic metals; creek water; Mahim Creek; Bandra ki Khadi; Mumbai

\section{INTRODUCTION}

Environmental problems concerning coastal and aquatic bodies cannot be addressed in isolation. They are intricately interwoven with each other. The environments of land and creek are interdependent, linked by complex atmospheric, geological, physical, chemical and biological interactions. Today it is realized that solution to environmental problem along the coastal and aquatic bodies can only be achieved through comprehensive, systematic and sustained approach. According to one study it is estimated that Mumbai city of India itself discharges around 2200 MLD of waste to the coastal waters [1]. Among the different pollutants entering the water bodies, heavy metals are of great concern. These toxic heavy metals entering the aquatic ecosystem may lead to geoaccumulation, bioaccumulation and biomagnifications; further they may also enter the food chain $[2,3]$. Food chain contamination by heavy metals has become a burning issue in recent years because of their potential accumulation in bio-systems through contaminated water [4-8].

In view of day by day increasing pollution issues related to the water bodies in Mumbai, city of India, we have initiated the study to understand the level of toxic heavy 
metals in the water samples collected along the Mahim Creek of Mumbai. Since the present study area receives heavy pollution load from the adjoining Mithi River and from the surrounding slum areas, it is expected that the results of our study will provide information regarding trend in heavy metal pollution load entering the creek.

\section{EXPERIMENTAL}

\section{1. Study Area}

The Mahim Creek (locally known as Bandra ki Khadi) is a creek in Mumbai, India. The famous Mithi River which is one of the most polluted river of Mumbai [9-14] drains into the creek which further drains into the Mahim Bay. It is the only Creek which balances the water level of Mumbai during heavy rainfall and during Mumbai monsoon time. The creek is the biggest sink for most of the waste generated by residential complexes and small scale industries. The waters of the creek are foul smelling due to the dumping of untreated industrial effluents further upstream. The creek is swamped by mangroves and has a miniecosystem within it. It is a less known fact that the Mahim bay area, where Mahim creek meets Arabian Sea, is a nominated bird sanctuary called "Salim Ali Bird Sanctuary" where migratory birds come for nesting. The Creek is located along western Arabian cost of India from $19^{\circ} 2$ ' $52.84^{\prime \prime}$ " north and from $72^{\circ} 50^{\prime} 17.56^{\prime}$ ' east. The depth of the creek is 15 feet $(4.6$ $\mathrm{m})$. The area experiences tropical savanna climate. It receives heavy south west monsoon rainfall, measuring $2166 \mathrm{~mm}$ on an average every year. The temperature ranges from $16{ }^{\circ} \mathrm{C}$ to $39{ }^{\circ} \mathrm{C}$ with marginal changes between summer and winter months. The relative humidity ranges between 54.5 to $85.5 \%$ [15].

\section{2. Requirements}

All the glassware, casserole and other pipettes were first cleaned with tape water thoroughly and finally with de-ionised distilled water. The pipettes and standard flasks were rinsed with solution before final use. The chemicals and reagent were used for analysis were of analytical reagent (A.R.) grade. The procedure for calculating the different parameters were conducted in the laboratory.

\section{3. Water sampling and sample preparation}

The study on pollution status along the Mahim creek of Mumbai was performed for the period of one year from June 2012 to May 2013. The sampling of creek water was done every month along different locations of the creek. The grab water samples were collected in polythene bottles of $2.5 \mathrm{~L}$. The bottles were thoroughly cleaned with hydrochloric acid, washed with distilled water to render free of acid, rinsed with the water sample to be collected and then filled with the sample leaving only a small air gap at the top. The sample bottles were stoppard and sealed using paraffin wax. The samples thus collected were mixed to give gross sample. Such gross samples were analysed every month for the toxic heavy metal content, so as to get the seasonal variation in pollution level along the Mahim Creek. For estimation of dissolved heavy metal content in water, the collected sample was filtered using Whatman No. 41 filter paper. Filtrate was preserved with $2 \mathrm{~mL}$ nitric acid to prevent the precipitation of metals. The sample was concentrated to tenfold on a water bath and subjected to nitric acid digestion using the microwave assisted technique $[16,17]$. 


\section{4. Quality control/assurance}

All glassware used were soaked in appropriate dilute acids overnight and washed with teepol and rinsed with deionised water before use. All instruments used were calibrated before use. Tools and work surfaces were carefully cleaned for each sample to avoid cross contamination. Triplicate samples were analysed to check precision of the analytical method and instrument.

\section{5. Analysis of Heavy Metals}

The water samples collected were analyzed for the heavy metal content. The analysis for the majority of the trace metals like lead $(P b)$, cadmium $(C d)$, chromium $(C r)$, Iron $(F e)$, zinc $(\mathrm{Zn})$, copper $(\mathrm{Cu})$ and nickel $(\mathrm{Ni})$ in water samples was done by Flame Atomic Absorption spectrophotometer $(A A S)$ technique, while analysis of mercury $(\mathrm{Hg})$ was performed by cold-vapour techniques [18] using Perkin Elmer Analyst 200 Flame Atomic Absorption Spectrophotometer (2003 model). The calibration curves were prepared separately for all the metals by running different concentrations of standard solutions. A reagent blank sample was run throughout the method, and the blank readings were subtracted from the samples to correct for reagent impurities and other sources of errors from the environment. Average values of three replicate analysis were calculated for each determination.

\section{RESULTS AND DISCUSSION}

Although there is no clear definition of what a heavy metal is, density is in most cases taken to be the defining factor. Heavy metals are thus generally defined as those having a specific density of more than $5 \mathrm{~g} / \mathrm{cm}^{3}$. Heavy metals are among the most common environmental pollutants, and their occurrence in waters and biota indicate the presence of natural or anthropogenic sources. Although adverse health effects of heavy metals have been known for a long time, discharge of heavy metals continues and is even increasing in some areas, in particular in less developed countries.

The main threats to human health from heavy metals are associated with exposure to lead, cadmium and mercury. Their accumulation and distribution in soil and aquatic environment are increasing at an alarming rate thereby affecting marine life [19-21]. The experimental data on concentration ( $\mathrm{ppm}$ ) of toxic heavy metals like $\mathrm{Pb}, \mathrm{Cd}, \mathrm{Cr}, \mathrm{Fe}, \mathrm{Zn}, \mathrm{Cu}$ and $\mathrm{Ni}$ and $\mathrm{Hg}$ in the water samples collected along the Mahim Creek of Mumbai is presented in Table 1. The annual average concentration of these metals is graphically represented in Figure 1.

The extensive studies [22-27] on ecological and toxicological aspects of lead $(\mathrm{Pb})$ and its compounds in the environment have revealed that $P b$ is neither essential nor beneficial to living organisms; all existing data show that its metabolic effects are adverse. It is toxic in most of its chemical forms and can be incorporated into the body by inhalation, ingestion, dermal absorption, and placental transfer to the foetus. 
Table 1. Heavy Metals in Mahim Creek water.

\begin{tabular}{|c|c|c|c|c|c|c|c|c|}
\hline $\begin{array}{l}\text { Heavy Metals } \\
(\text { ppm })\end{array}$ & $\mathrm{Pb}$ & $\mathrm{Cd}$ & $\mathrm{Cr}$ & $\mathrm{Fe}$ & $\mathrm{Zn}$ & $\mathrm{Cu}$ & $\mathrm{Ni}$ & $\mathrm{Hg}$ \\
\hline \multicolumn{9}{|l|}{ Months/Year } \\
\hline June 2012 & 1.25 & 0.34 & 0.28 & 0.03 & 2.36 & 1.56 & 3.76 & 0.73 \\
\hline July 2012 & 1.38 & 0.10 & 0.09 & 0.02 & 8.05 & 2.12 & 3.23 & 0.97 \\
\hline August 2012 & 1.22 & ND & ND & 0.04 & 7.36 & 1.05 & 2.32 & 0.35 \\
\hline September 2012 & 0.95 & ND & ND & 0.06 & 2.35 & 0.35 & 1.19 & 0.21 \\
\hline October 2012 & 0.75 & 0.02 & ND & 0.04 & 2.31 & 0.43 & 0.96 & 0.25 \\
\hline November 2012 & 0.63 & 0.05 & 0.06 & 0.04 & 2.18 & 0.36 & 0.93 & 0.19 \\
\hline December 2012 & 0.50 & 0.20 & 0.09 & 0.02 & 1.98 & 0.31 & 0.85 & 0.22 \\
\hline January 2013 & 0.49 & 0.30 & 0.20 & 0.02 & 1.65 & 0.36 & 0.63 & 0.20 \\
\hline February 2013 & 0.38 & 0.49 & 0.18 & 0.01 & 1.73 & 0.26 & 0.74 & 0.18 \\
\hline March 2013 & 0.20 & 0.55 & 0.24 & 0.03 & 1.30 & 0.29 & 0.36 & 0.16 \\
\hline April 2013 & 0.22 & 0.60 & 0.30 & 0.04 & 1.68 & 0.32 & 0.28 & 0.15 \\
\hline May 2013 & 0.24 & 0.72 & 0.38 & 0.08 & 2.20 & 0.27 & 0.25 & 0.16 \\
\hline
\end{tabular}

$\mathrm{ND}=$ Not Detected

It is an accumulative metabolic poison that affects behaviour, as well as the hematopoietic, vascular, nervous, renal, and reproductive systems. From the results of present investigation, it was observed that the concentration of $P b$ in the creek water was found to vary in the range of 0.20 to $1.38 \mathrm{ppm}$ with an annual average concentration of $0.68 \mathrm{ppm}$. $\mathrm{Cu}$ is highly toxic to most fishes, invertebrates and aquatic plants than any other heavy metal except mercury. It reduces growth and rate of reproduction in plants and animals. The chronic level of $\mathrm{Cu}$ is 0.02-0.2 ppm [28]. Aquatic plants absorb three times more $\mathrm{Cu}$ than plants on dry lands [29]. Excessive $C u$ content can cause damage to roots, by attacking the cell membrane and destroying the normal membrane structure, inhibited root growth and formation of numerous short, brownish secondary roots [28]. Copper is highly toxic in aquatic environments and has effects in fish, invertebrates, and amphibians, with all three groups equally sensitive to chronic toxicity [30,31].

Copper will bio concentrate in many different organs in fish and mollusks. Copper also causes reduced sperm and egg production in many species of fish, such as fathead minnows, as well as early hatching of eggs, smaller fry (newly hatched fish) and increased incidence of abnormalities and reduced survival in the fry [32]. 


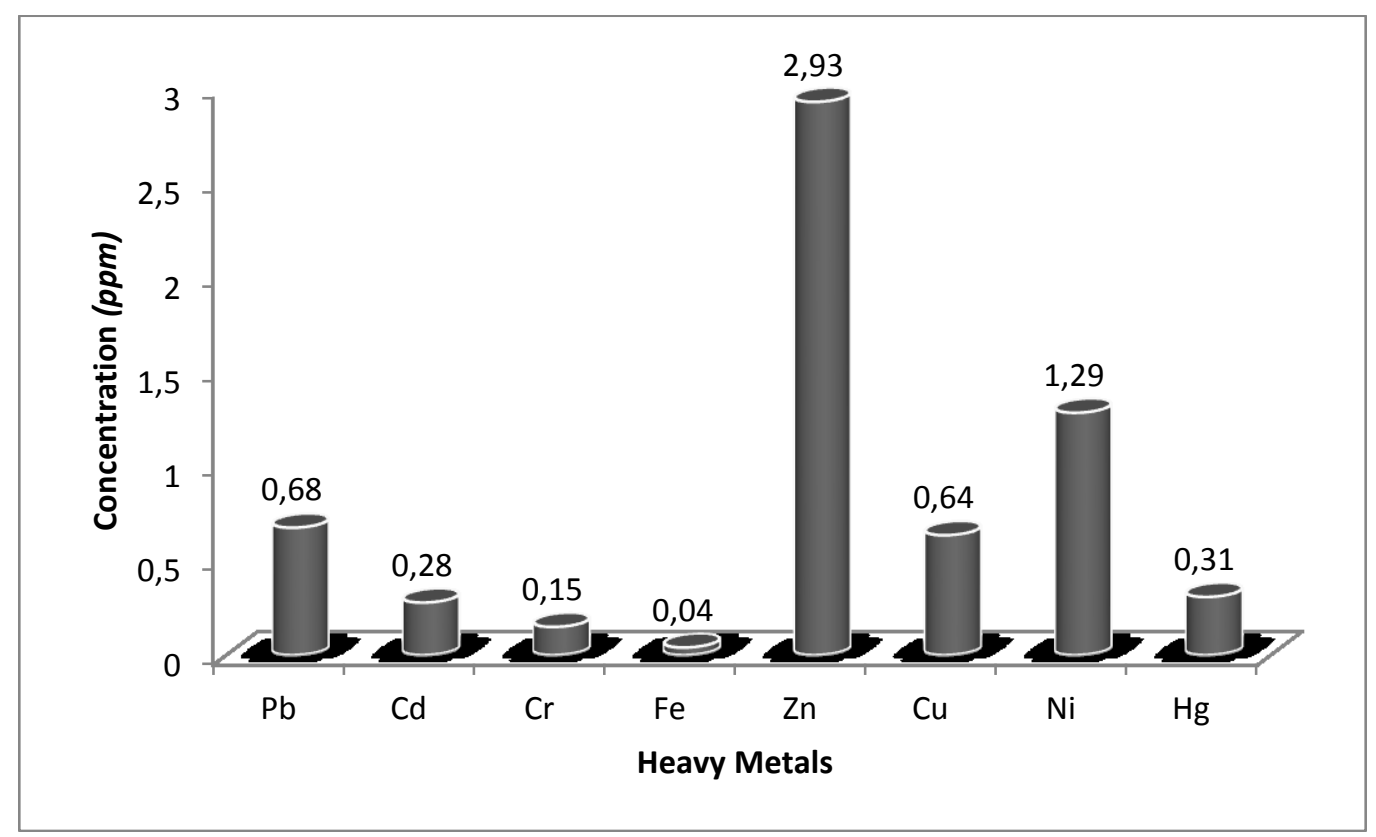

Figure 1. Annual average concentrations of toxic heavy metals in water of Mahim Creek near Mumbai.

In the present study it was observed that the $C u$ concentration in the water samples was found to be minimum of $0.26 \mathrm{ppm}$ in the month of February and maximum of $2.12 \mathrm{ppm}$ in the month of July. The annual average concentration of $C u$ was found to be $0.64 \mathrm{ppm}$.

The concentration of $Z n$ in the creek water was found to vary in the range of 1.30 in the month of March to $8.05 \mathrm{ppm}$ in the month of July having an annual average concentration of $2.93 \mathrm{ppm}$. Nickel $(\mathrm{Ni})$ and nickel compounds have many industrial and commercial uses, and the progress of industrialization has led to increased emission of pollutants into ecosystems. The results of our study indicates that the concentration of $\mathrm{Ni}$ in the water was minimum of $0.25 \mathrm{ppm}$ in the month of May and $3.76 \mathrm{ppm}$ in the month of June, having annual average concentration of $1.29 \mathrm{ppm}$. Although $\mathrm{Ni}$ is omnipresent and is vital for the function of many organisms, concentrations in some areas from both anthropogenic release and naturally varying levels may be toxic to living organisms [33,34]. Nickel compounds have been well established as carcinogenic in many animal species and by many modes of human exposure but their underlying mechanisms are still not fully understood [35]. Cadmium $(C d)$ is typically a metal of the $20^{\text {th }}$ century, and is mainly used in rechargeable batteries and for the production of special alloys. It was the outbreak of the Itai-Itai bone disease in Japan in the 1960 s that really drew the attention of the public and regulatory bodies to this heavy metal that had been discharged in the environment at an uncontrolled rate for more than one century. From the results of our study it was observed that the $C d$ concentration in the creek water samples was maximum of $0.72 \mathrm{ppm}$ in the month of May, having an annual average concentration of $0.28 \mathrm{ppm}$. $C d$ dispersed in the environment can persist in soils and sediments for decades. When taken up by plants, $C d$ concentrates along the food chain and ultimately accumulates in the body of people eating contaminated foods. By far, the most salient toxicological property of $C d$ is its exceptionally long half-life in the human body. 
Once absorbed, $C d$ irreversibly accumulates in the human body, in particularly in kidneys, the bone, the respiratory tract and other vital organs such the lungs or the liver [36]. In addition to its extraordinary cumulative properties, $C d$ is also a highly toxic metal that can disrupt a number of biological systems, usually at doses that are much lower than most toxic metals [37-39]. Mercury $(\mathrm{Hg})$ poisoning has become a problem of current interest as a result of environmental pollution on a global scale. High concentration of mercury, which could pose an ecological hazard, leading to contamination of plants, aquatic resources and bioaccumulation in the food chain [40]. In the present investigation it was observed that the concentration of $\mathrm{Hg}$ in the water was in the range of 0.15 to $0.97 \mathrm{ppm}$ having the annual average concentration of $0.31 \mathrm{ppm}$. Chromium $(\mathrm{Cr})$ is one of the most common skin sensitizers and often causes skin sensitizing effect in the general public. A possible source of chromium exposure is waste dumps for chromate-producing plants causing local air or water pollution. Penetration of the skin will cause painless erosive ulceration ("chrome holes") with delayed healing. These commonly occur on the fingers, knuckles, and forearms. The characteristic chrome sore begins as a papule, forming an ulcer with raised hard edges. Besides the lungs and intestinal tract, the liver and kidney are often target organs for chromate toxicity [41-45]. In the present investigation it was observed that the concentration of $\mathrm{Cr}$ in the water samples was maximum of $0.38 \mathrm{ppm}$ in the month of May, having the annual average concentration of $0.15 \mathrm{ppm}$.

\section{CONCLUSIONS}

Around the world as countries are struggling to arrive at an effective regulatory regime to control the discharge of industrial effluents into their ecosystems, Indian economy holds a double edged sword of economic growth and ecosystem collapse. As India progresses towards strict regulation of industrial effluents to control water pollution, greater efforts are required to reduce the risk to public health as colourless and odourless toxic pollutants are released into the ecosystems. Hence there is a need that each industry should treat their effluents, in accordance with the legal requirements, before discharging these into the streams otherwise 'Polluter pays' principle should be implemented. The current regulatory system in India for control of industrial discharges needs a complete improvement in terms of standards setting, monitoring and enforcement. The monitoring system for water quality needs to be strengthened both in terms of parameters monitored, water resources coverage and timely reporting to public domain. These steps are important in order to avoid irreparable ecological harm in the long term well masked by short term economic prosperity due to extensive industrial growth. 


\section{References}

[1] M.D. Zingde, K. Govindan, Health status of coastal waters of Mumbai and regions around. In: Environmental Problems of Coastal Areas in India (ed. V.K. Sharma), Bookwell Publishers., New Delhi, pp. 119-132 (2001).

[2] P.U. Singare, M.S. Talpade, D.V. Dagli, V.G. Bhawe, International Letters of Chemistry, Physics and Astronomy 8(2) (2013) 105-112.

[3] P.U. Singare, M.S. Talpade, Interdisciplinary Environmental Review 14(1) (2013) 59-68.

[4] M.C. Kennicutt, T.L. Wade, B.J. Presley, A.G. Requejo, J.M. Brooks, G.J. Denoux, Environ. Sci. Technol. 28 (1993) 1.

[5] W.J. Adams, R.A. Kimerle, J.W.Barnett Jr., Environ Sci Technol. 26 (1992) 1864.

[6] R.K. Sharma, M. Agrawal, F.M. Marshall, 'Effects of waste water irrigation on heavy metal accumulation in soil and plants', Paper presented at a National Seminar, Bangalore University, Bangalore, Abst. no. 7, pp. 8 (2004).

[7] D.P. Weston, K.A. Maraya, Environ. Toxicol. Chem. 21 (2002) 962.

[8] A. Kumar, Pol. Arch. Hydrobiol. 18 (1996) 469.

[9] P.U. Singare, Asian Journal of Environment and Disaster Management 4(3) (2012) 323-332.

[10] P. U. Singare, R.M. Mishra, M.P. Trivedi, Advances in Analytical Chemistry 2(3) (2012) 14-24.

[11] P. U. Singare, R.M. Mishra, M.P. Trivedi, Frontiers in Science 2(3) (2012) 28-36.

[12] P. U. Singare, R.M. Mishra, M.P. Trivedi, Interdisciplinary Environmental Review, 13(4) (2012) 245-268.

[13] P. U. Singare, R.M. Mishra, M.P. Trivedi, Resources and Environment 1(1) (2011) $32-41$.

[14] Klean Environmental Consultants Pvt. Ltd., Mumbai, Survey Report on Mithi River Water Pollution and Recommendations for its Control', Report Submitted To Maharashtra Pollution Control Board (MPCB), Mumbai. Ref.No.0407/Mpcb Mithi River Survey/ 109, July 10, 2004.

[15] P.U. Singare, Marine Science 2(1) (2012) 1-5.

[16] L.S. Clesceri, Standard methods for the examination of water and waste water. In Collection and Preservation of Samples and Metals (eds. E. Arnold, Greenbergy, A.D. Eaton), APHA, AWWA, WEF, Washington, DC, pp. 1-27-1-35; 3-1-3-21, (1998).

[17] A. Paar, Microwave Sample Preparation System - Instruction Handbook, Anton Paar GmbH, Austria, pp. 128, (1998).

[18] G.H. Jeffery, J. Bassett, J. Mendham, R.C. Denny, Vogel's Textbook of Quantitative Chemical Analysis, Longman Scientific \& Technical, England, $5^{\text {th }}$ Edition, 1989, pp. 87,788 . 
[19] B. Koukal, J. Dominik, D. Vignati, P. Arpagaus, S. Santiago, B. Ouddane, L. Benaabidate, Environ. Poll. 131(1) (2014) 163-172.

[20] K.M. Mohiuddin, H.M. Zakir, K. Otomo, S. Sharmin, N. Shikazono, Int. J. Environ. Sci. Tech. 7 (1) (2010) 17-28.

[21] E.C. Okafor, K. Opuene, Int. J. Environ. Sci. Tech. 4(2) (2007) 233-240.

[22] EPA. Ambient water quality criteria for lead - 1984. U.S. Environ. Protection Agency Rep. 440/5-84-027. pp.81 Available from Natl. Tech. Infor. Serv., 5285 Port Royal Road, Springfield, Virginia 22161 (1985).

[23] J.S. Feierabend, A.B. Russell, (eds.), Lead poisoning in wild waterfowl - a workshop. National Wildlife Federation, 1412 Sixteenth St. NW, Washington, D.C. pp.139 (1986).

[24] FWS. Use of lead shot for hunting migratory birds in the United States. Final supplemental environmental impact statement. pp.535 Available from U.S. Fish Wildlife Service, Office of Migratory Bird Management, Washington, D.C. 20240 (1986).

[25] R. Lansdown, W. Yule (eds.), Lead toxicity. History and environmental impact, Johns Hopkins Univ. Press, Baltimore, Maryland. 1986, pp. 286

[26] L .J. McDonald, Can. Vet. J. 27(3) (1986) 131-134.

[27] G.C. Sanderson, F.C. Bellrose, Illinois Natural History Survey, (SP-04) (1986) 1-34.

[28] N.S. Tiwana, N. Jerath, G. Singh, M. Ravleen (Eds.), Heavy metal pollution in Punjab Rivers, in Newsletter Environmental Information System (ENVIS), Punjab State Council for Science and Technology, India, 3(1) (2005).

[29] Centre for Ecological Sciences., IISc Environmental Hand Book - Documentation on Monitoring and Evaluating Environmental Impacts, of Environmental Standards, Vol.3, Indian Institute of Science, Bangalore (2001).

Available at http://wgbis.ces.iisc.ernet.in/energy/HC270799/HDL/ENV/START.HTM (Accessed on 01 March 2010).

[30] US EPA. Wildlife Exposure Factor Handbook. Vol. 1 EPA/600/R-93/187a (1993).

[31] M.T. Horne, W.A. Dunson, Archives of Environmental Contamination and Toxicology 29(4) (1995) 500-505.

[32] B. Taub Frieda, Fish 430 lectures (Biological Impacts of Pollutants on Aquatic Organisms), University of Washington College of Ocean and Fishery Sciences, Seattle, WA (2004).

[33] L.T. Haber, L. Erdreicht, G.L. Diamond, A.M. Maier, R. Ratney, Q. Zhao, M. Dourson, Regul. Toxicol. Pharmacol. 31(2) (2000) 210-230.

[34] V. Diagomanolin, M. Farhang, M. Ghazi-Khansari, N. Jafarzadeh, Iran, Toxicol. Lett. 151(1) (2004) 63.

[35] F.W. Sunderman, S.M. Hopfer, M.C. Plowman, J.A Knight, Res. Commun. Chem. Pathol. Pharmacol. 70(1) (1990) 103.

[36] N. Johri, G. Jacquillet, R. Unwin, BioMetals 23(5) (2010) 783-792. 
[37] G. Nordberg, K. Nogawa, M. Nordberg, L. Friberg, Cadmium. In: Handbook on toxicology of metals. Nordberg, G., Fowler, B., Nordberg, M., Friberg, L. editors New York: Academic Press, 2007, p. 65-78.

[38] A. Bernard, Biometals 17(5) (2004) 519-523.

[39] J. Godt, F. Scheidig, C.G. Siestrup, V. Esche, P. Brandenburg, A. Reich, D.A. Groneberg, J. Occup. Med. Toxicol. 1 (2006) 22.

[40] L. Favretto, B. Campisi, E. Reisenhofer, G. Adami, Anal. Chim. Acta, 344(3) (1997) 251-259.

[41] W.N. Rom, Environmental and Occupational Medicine. $4^{\text {th }}$ Ed. by Lippincott Williams \& Wilkins (2007).

[42] Pravin U. Singare, M. V. A. Ansari, N. N. Dixit, International Letters of Natural Sciences 10 (2014) 69-78.

[43] Pravin U. Singare, M. V. A. Ansari, N. N. Dixit, International Letters of Natural Sciences 10 (2014) 79-88.

[44] Pravin U. Singare, M. V. A. Ansari, N. N. Dixit, International Letters of Natural Sciences 11(1) (2014) 44-53.

[45] Pravin U. Singare, M. V. A. Ansari, N. N. Dixit, International Letters of Natural Sciences 11(1) (2014) 54-61. 